\title{
Sprawozdanie z uroczystej sesji nt. „Lech Mokrzecki - 50 lat w służbie historii nauki, kultury i edukacji" zorganizowanej przez Zakład Historii Nauki, Oświaty i Wychowania Instytutu Pedagogiki UG w dniu 28 lutego 2007 r.
}

W bieżącym roku przypada pięćdziesiąta rocznica podjęcia pracy zawodowej przez prof. zw. dr hab. Lecha Mokrzeckiego - wieloletniego kierownika Zakładu Historii Nauki, Oświaty i Wychowania UG. Z tej okazji w Instytucie Pedagogiki Uniwersytetu Gdańskiego 28 lutego 2007 r. odbyła się uroczysta sesja zorganizowana przez Zakład Historii Nauki, Oświaty i Wychowania nt. „Lech Mokrzecki - 50 lat w słuźbie historii nauki, kultury i edukacji". Tytuł sesji wydaje się być jak najbardziej zasadny, gdyż prof. L. Mokrzecki jest nie tylko cenionym badaczem dziejów oświaty, nauczycielem akademickim, wychowawcą wielu pokoleń pedagogów, ale także absolwentem klasy wiolonczeli Państwowej Wyższej Szkoły Muzycznej w Gdańsku, byłym muzykiem Państwowej Opery i Filharmonii Bałtyckiej oraz profesorem zwyczajnym Akademii Muzycznej w Gdańsku.

W Jubileuszu Profesora L. Mokrzeckiego wzięło udział ponad stu pięćdziesięciu gości z całej Polski. Uczestniczyli w nim reprezentanci m.in.: Uniwersytetu Jagiellońskiego w Krakowie, Uniwersytetu Warszawskiego, Uniwersytetu im. Adama Mickiewicza w Poznaniu, Uniwersytetu im. Mikołaja Kopernika w Toruniu, Uniwersytetu Wrocławskiego, Uniwersytetu Śląskiego, Uniwersytetu im. Kazimierza Wielkiego w Bydgoszczy, Uniwersytetu Marii Curie-Skłodowskiej w Lublinie, Szkoły Głównej Gospodarstwa Wiejskiego w Warszawie, Akademii im. Jana Długosza w Częstochowie oraz Akademii Pomorskiej w Słupsku. Nie zabrakło oczywiście przedstawicieli władz macierzystej uczeIni Jubilata, które reprezentowali: prof. dr hab. Bernard Lammek - Prorektor ds. Nauki, dr Jacek Taraszkiewicz - Prorektor ds. Studenckich, mgr Piotr Żerko - Kanclerz UG, prof. dr hab. Henryk Machel - Dziekan Wydziału Nauk Społecznych oraz prof. dr hab. Maria Mendel - Dyrektor Instytutu Pedagogiki. Na sesję przybyli także przedstawiciele innych gdańskich uczelni, z którymi prof. L. Mokrzecki przez lata pracy zawodowej był związany: prof. dr hab. Waldemar Tłokiński - Rektor „Ateneum” - Szkoły Wyższej w Gdańsku, prof. Marcin Tomczak - Prorektor Akademii Muzycznej w Gdańsku wraz z prof. Maciejem Sobczakiem - Dziekanem II Wydziału oraz prof. Markiem Rocławskim - Dziekanem IV Wydziału tej uczelni, dr Iwona Sitkiewicz-Icha - Dziekan Gdańskiej Wyższej Szkoły Humanistycznej. Uczestniczyli w Sesji również współpracownicy, rodzina, przyjaciele, koledzy i koleżanki Jubilata z czasów szkolnych i okresu studiów oraz absolwenci Profesora.

Pierwsze dwie części uroczystości, które poprowadził dr Józef Żerko, odbyły się w budynku IP UG. Jubilata i zebranych gości oficjalnie powitał prof. dr hab. Romuald Grzybowski - następca prof. L. Mokrzeckiego na stanowisku kierownika Zakładu Historii Nauki, Oświaty i Wychowania UG. W imieniu społeczności Instytutu Pedagogiki serdeczne słowa do Profesora skierowała Dyrektor IP UG prof. dr hab. Maria Mendel.

Po uroczystym rozpoczęciu Sesji prof. R. Grzybowski w wystąpieniu pt. „Gdańska historia oświaty - tradycje i perspektywy" nakreślił dokonania oraz sylwetki twórców 
Zakładu Historii Nauki, Oświaty i Wychowania UG. Przypomniał założyciela zakładu prof. Kazimierza Kubika, jego uczniów i współpracowników: prof. Klemensa Trzebiatowskiego, dr Jerzego Szewsa, doc. Wiktora Frąckowiaka i dr Józefa Żerkę. Podkreślił, że najwybitniejszym wychowankiem prof. K. Kubika jest prof. L. Mokrzecki. Odnosząc się do obecnej sytuacji Zakładu Historii Nauki, Oświaty i Wychowania UG prof. R. Grzybowski zasygnalizował zasadnicze kierunki badań w nim realizowanych oraz zwrócił uwagę na aktualne tendencje w podejściu do historii wychowania w uczelniach polskich.

Następnie głos zabrała dr Lidia Burzyńska-Wentland, która przybliżyła dorobek naukowy i osiągnięcia dydaktyczne oraz wkład prof. L. Mokrzeckiego w dzieło szerzenia kultury muzycznej. Ze względu na rozległość zagadnienia i ograniczenia czasowe przypomniała tylko tytuły pozycji książowych Jubilata oraz zasygnalizowała główne kierunki badań przez niego podejmowanych. Odniosła się też do niepodważalnych zasług Profesora na gruncie kształcenia młodej kadry naukowej.

Kolejnym referentem był sam Jubilat, który w wystąpieniu pt.: „Czterdzieści lat w cieniu Gdańskiego Gimnazjum Akademickiego” stwierdził m.in., że zainteresowanie tą najznakomitszą gdańską szkołą okresu staropolskiego jest niejako klamrą spinającą całość jego aktywności naukowej. Na niej jako młody badacz historii wychowania skupił swoją uwage, co znalazło wyraz w rozprawie doktorskiej przygotowanej pod kierunkiem prof. K. Kubika. Obecnie zaś, po wielu latach, Gdańskie Gimnazjum Akademickie jest na powrót obiektem Jego zainteresowań, ponieważ partycypuje On w przygotowaniu mających się niebawem ukazać dwóch tomów dokumentów oraz publikacji dotyczącej działalności tej szkoły w XVI-XVIII w. Prof. L. Mokrzecki zaznaczył, że Gdańskie Gimnazjum Akademickie wzbudziło zainteresowanie badaczy historii oświaty dopiero po II wojnie światowej, za sprawą prac prof. Bronisława Nadolskiego i prof. Kazimierza Kubika z Wyższej Szkoły Pedagogicznej w Gdańsku. Później badania naukowe nad wyjątkowym znaczeniem Prus Królewskich w dziedzinie edukacji w dobie Pierwszej Rzeczypospolitej, poza Jubilatem, prowadzili Stanisław Salmonowicz, Tadeusz Bieńkowski, Marian Pawlak, Edmund Kotarski, Zbigniew Nowak oraz ostatnio Edmund Kizik.

Zakończenie pierwszej części jubileuszowej sesji zwieńczył występ byłych uczniów i studentów prof. L. Mokrzeckiego z Akademii Muzycznej w Gdańsku. Trio „Nowe” w składzie: Maciej Sobczak - skrzypce, Jerzy Wujtewicz - wiolonczela, Bogumiła Weretka-Bajdor - pianino wykonało cz. I: Allegro i cz. II: Presto Tria C-dur W. A. Mozarta (KV 548).

Po przerwie głos zabrał prof. dr hab. Wiesław Jamrożek z Uniwersytetu im. A. Mickiewicza w Poznaniu, recenzent Księgi pamiątkowej wydanej z okazjji Jubileuszu prof. L. Mokrzeckiego ( $W$ stużbie historii nauki, kultury i edukacji. Księga Pamiqtkowa dedykowana Prof. Lechowi Mokrzeckiemu z okazji Jubileusz Pięćdziesięciolecia Pracy Zawodowej, pod red. R. Grzybowskiego i T. Maliszewskiego, Wydawnictwo Uniwersytetu Gdańskiego, Gdańsk 2006). Prof. W. Jamrożek w imieniu własnym i poznańskich współpracowników złożył Jubilatowi podziękowania za to, że przez wiele lat był dla nich wzorem uczonego otwartego na drugiego człowieka, dialog i współpracę. Podkreślił też, że osobowość prof. L. Mokrzeckiego jest zespoleniem cech wrażliwego na piękno artysty i niestrudzonego w poszukiwaniu prawdy badacza, a dedykowana Profesorowi Księga Pamiątkowa syntezę tę doskonale oddaje. 
Następnie dr Tomasz Maliszewski zaprezentował fragmenty wywiadu-rzeki, który przeprowadził z prof. L. Mokrzeckim w 2006 r. Portret „Profesora jakiego nie znamy” nakreślony przez referenta rzucił nowe światło na osobowość Jubilata oraz zachęcił zebranych do zapoznania się ze wspomnieniami prof. L. Mokrzeckiego m.in. o rodzime, latach szkolnych i studenckich zamieszczonych w Księdze Pamiątkowej.

W kolejnym punkcie przybyli na Sesje przedstawiciele władz Uniwersytetu Gdańskiego uroczyście wręczyli prof. L. Mokrzeckiemu dedykowaną Mu Księgę Pamiątkową.

Na zakończenie drugiej części Sesji wystąpił Akademicki Chór Uniwersytetu Gdańskiego pod dyrekcją prof. Marcina Tomczaka. Warto zaznaczyć, że obecność na uroczystości chóru nie była przypadkowa, prof. L. Mokrzecki był bowiem jego współzałożycielem i opiekunem już od początku lat $70 . \mathrm{XX}$ w.

Trzecia część Jubileuszu odbyła się w restauracji „Menadżer” w Gdańsku-Jelitkowie, gdzie prof. L. Mokrzecki podjął uroczystym obiadem i poczęstunkiem około stu trzydziestu zaproszonych gości. Te mniej oficjalne warunki stworzyły doskonałą okazję do złożenia Jubilatowi osobistych życzeń i gratulacji, a prof. L. Mokrzeckiemu do podarowania wielu uczestnikom tej części Sesji opatrzonej autografem Księgi Pamiątkowej.

Anna Paszkowska

\section{Międzynarodowa Konferencja Naukowa pt. „Mężczyzna w rodzinie i społeczeństwie - ewolucja ról w kulturze polskiej i europejskiej od średniowiecza do końca XX wieku”, Ciążeń, 9-11 września 2007}

Tematyka gender studies od szeregu lat cieszy się ogromnym zainteresowaniem, mającym przełożenie w liczbie publikacji, organizowanych sympozjów naukowych czy w realizowanych projektach badawczych. Problematyka roli kobiety w rodzinie i społeczeństwie, pozycja dziecka w relacjach rodzinnych i na zewnątrz znalazły się również w kręgu zainteresowań naukowych poznańskiego środowiska historyków wychowania, organizujących bądź też współuczestniczących w organizacji konferencji naukowych, tworzących pewną spójność problematyczną i stąd zasługujących na miano cyklicznych.

Tegoroczne spotkanie, które miało miejsce w dawnym pałacu biskupów poznańskich w Ciążeniu, będącym obecnie własnością poznańskiego uniwersytetu miało szczególny charakter, choćby $\mathrm{z}$ racji dużego zainteresowania uczonych reprezentujących niemal wszystkie liczące się ośrodki naukowe w Polsce oraz udziału naukowców z Czech, Słowacji, Słowenii i Ukrainy. Ponadto poszerzono tematykę poruszoną podczas dotychczasowych konferencji, których celem było poznanie pozycji społecznej rodziny i jej członków na przestrzeni wieków - od średniowiecza do współczesności. Przypomnieć warto, że tematami poprzednich spotkań były kobiety (1997 - „Rola i miejsce kobiet 